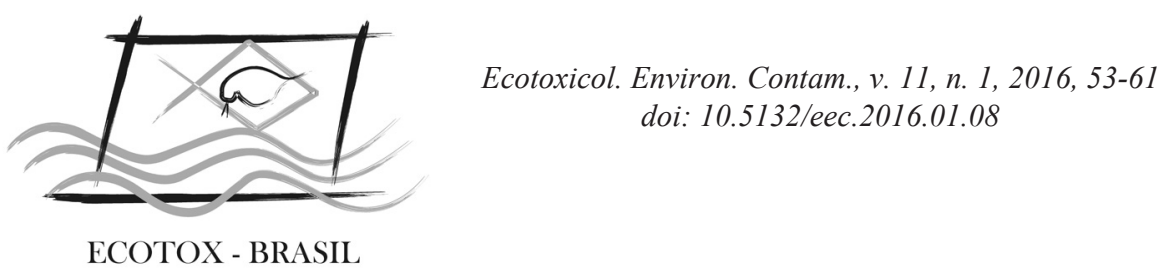

\title{
Confounding factors in biomonitoring using fish
}

\author{
Dalzochio, T.\& Gehlen, G. \\ Programa de Pós-Graduação em Qualidade Ambiental, Universidade Feevale \\ RS 239, 2755, CEP 93352-000, Novo Hamburgo, RS, Brazil
}

(Received February 20, 2014; Accept September 14, 2016)

\begin{abstract}
Pollution of water ecosystems is considered one of the most serious problems in the current days. In order to predict the effects of pollutants present in the water before overt disease and/or death in aquatic biota, bioindicators, as fish, and biomarkers have been widely used in biomonitoring studies. Notwithstanding, biomarkers responses might be modulated by non-pollutant factors and not only by environmental contaminants. As these premises are not always observed, this review attempts to explore confounding factors related to the modulation of the biomarker responses applied in biomonitoring studies. Among others, gender, temperature and feeding habitat are some factors which affect biomarker responses. However, the use of this tool is still important to assess the health of aquatic ecosystems. Thus, it is strongly recommended to use different biomarkers and, whenever possible, to analyze water and sediment physicochemical parameters.
\end{abstract}

Keywords: biomarkers; biomonitoring; fish; pollution; environment; environmental quality; water resources.

\section{INTRODUCTION}

Efforts have been ongoing in many countries to develop integrated ecosystem-based assessments using physicochemical properties, biological abundance and diversity, and/or chemical characterization to define the ecological quality of aquatic environments (Hellou, 2011). Pollution, loss of biodiversity and habitat destruction are probably the main environmental threats for aquatic ecosystems (Linde-Arias et al., 2008a). Increasing number and amount of industrial, agricultural and commercial chemicals discharged into the aquatic environment have led to various deleterious effects on the aquatic organisms (McGlashan \& Hughies, 2001; Procópio et al., 2014). Bioconcentrations of highly persistent pollutants such as polychlorinated biphenyls (PCBs), polycyclic aromatic hydrocarbons (PAHs), organochlorine pesticides and toxic metals in species of marine organisms, and/or biomagnifications along the trophic chain, are considered one of the mayor threats to human and ecosystem health (Tomasello et al., 2012). In an attempt to monitor adverse effects caused by pollution, bioindicator organisms and biomarkers have been widely used as tools in environmental diagnose.

Fish are widely used as biondicator organisms and they represent the most feasible organisms for pollution monitoring in aquatic systems (Linde-Arias et al., 2008b). Fish can be found virtually everywhere in the aquatic environment and they play a major ecological role in aquatic food-webs because of their function as carrier of energy from lower to higher trophic levels (van der Oost et al., 2003).

Aquatic organisms are exposed to a wide variety of environmental contaminants. Thus, a set of biomarkers is frequently employed to assess the possible biological impacts and environmental quality. Biomarkers are increasingly worldwide-recognized tools for the assessment of pollution impacts in the aquatic environment, and some of them are already incorporated in environmental monitoring programs (Viarengo et al., 2007). Biomarkers can be characterized as functional measures of exposure to stressors, which are usually expressed at the subcellular level of biologic organization (Adams et al., 2001). Subcellular responses to environmental stressors occur before other disturbances, such as disease, mortality, or 
population changes, and thus may offer early warnings of pollution impacts (Depledge \& Fossi, 1994).

The application of biomarkers for environmental monitoring requires an extensive knowledge of natural variability of biomarker responses. A number of factors such as sex, age, season, spawning period, variability of feeding habitats, pollutant exposure and phylogenetical differences in regulatory mechanisms may influence the uptake, retention and bioaccumulation of trace contaminants in fish tissues (Nesto et al., 2007), consequently affecting biomarker responses. The main confounding factors which might interfere in biomarker responses discussed in this review are listed in table 1. This poses careful interpretation of biomarker responses per se, since increased or decreased responses might be due to nonpollutant factors and be unrelated to exposure to chemical pollution. Nevertheless, the aim of this study is to gather data regarding confounding factors in the biomarkers used in fish in biomonitoring studies.

\section{Tissue differences of pollutants accumulation (metals and PAHs)}

Bioaccumulation of pollutants is usually employed combined with water physicochemical analysis or with other biomarkers. This analysis has been useful in order to correlate concentration of pollutants in the water/sediment and in fish tissues; and to assess chronic exposure to pollutants. The body content of a trace metal in a given organism results from the net balance between the processes of metal uptake and metal elimination (Birungi et al., 2007; Paulino et al., 2014). The rate of bioaccumulation of pollutants in fish might be higher or lower depending on the analyzed tissue. In the case of the grass goby (Tridentiger bifasciatus), a near-botton feeder,

Table 1: Main confounding factors which might affect biomarker responses to pollutants

Biomarker
Acetylcholinesterase (AChE) and

cholinesterase (ChE) activity

Bioaccumulation of metals in tissues

Bioaccumulation of polycyclic aromatic hydrocarbons (PAHs)

Condition factor

Gonado-somatic index

Ethoxyresorufin O-deethylase (EROD)

Glutathione peroxidase (GPx)

Glutathione S-transferase (GST)

Heat Shock Protein 70 (HSP70)

Lipid peroxidation (LPO)

Metallothioneins (MTs)

Superoxide dismutase (SOD) and catalase (CAT)
Likely affected by

Presence of arsenic, copper and mercury, detergents, seasonal variation and temperature

Tissue itself, feeding habitat, presence of ions of calcium (for manganese and copper accumulation) and copper (for zinc accumulation)

Nutritional status and metabolic rate

Disease, nutritional status and seasonal variation

Nutritional status and seasonal variation

Age, estradiol, gender, presence of copper and cadmium, seasonal variation and temperature

Seasonal variation

Gender, physiological factors, seasonal variation and spawning period.

Nutritional status, temperature, water physicochemical parameters

Feeding habitat

Age, gender, breeding period, presence of organic contaminants, seasonal variation, temperature and tissue

Age, feeding habitat and nutritional status

\section{Reference}

Lagadic et al., 1994; Guilhermino et

al., 1998; Beauvais et al., 2002; Phillips

et al., 2002; Napierska \& Podolska,

2005; Pfeifer et al., 2005; Kopecka \&

Pempkowiak, 2008; Durieux et al., 2011;

Jolly et al., 2012; Botté et al., 2013

Roch et al., 1985; Seymore et al., 1995;

Dallas \& Day, 1995; Croteau et al., 2005; Birungi et al., 2007

Collier \& Varanasi, 1991; Brumley et al., 1998

Mayer et al., 1992

Nesto et al., 2007

Förlin \& Andersson, 1984; Andersson \& Förlin, 1992; Roméo et al., 1994; Whyte et al., 2000; van der Oost et al., 2003;

Kashiwada et al., 2007; Guilherme et al., 2008; Vieira et al., 2009; Wunderlich et al., 2015

Sanchez et al., 2007; Jolly et al., 2012

Elia et al., 2003; Vieira et al., 2009;

Jolly et al., 2012

Stegeman et al., 1992; Di Giulio et al., 1995; van der Oost et al., 2003

Radi et al., 1985

Gerpe et al., 2000; van der Oost et al., 2003; Sokolova \& Lanning, 2008;

Rhee et al., 2009; Fonseca et al., 2011; Shariati \& Shariati, 2011; Carvalho et al., 2012; Siscar et al., 2014

Radi et al., 1985; Mourente et al., 2002; Rueda-Jasso et al., 2004; Ameur et al., 2012; Hook et al., 2014 
sediments may also play an important role as a source of contaminated food (Croteau et al., 2005). This correlation between metals in fish tissues and sediment has been found in some studies (Nesto et al., 2007; Weber et al., 2013).

Gills are central in the uptake of dissolved substances from water representing the prime target for toxic action of waterborne metals (Soto et al., 2003). Therefore, concentrations of metals might be higher in this organ. This finding has been reported in a study which analyzed metals in gills, liver and muscle. Metal concentration was higher in the gills and lower in the muscle (Birungi et al., 2007). On the other hand, considering the liver is the main organ responsible for biodegradation, Paulino et al. (2014) observed higher concentrations of contaminants in the liver of Astyanax fasciatus and Pimelodus maculates when compared to the gills.

Although the rate of accumulation might be influenced by the feeding habitat of the fish species and the analyzed tissue, it might also be influenced by the presence of certain ions. Calcium concentrations in the water might play a role in copper and manganese accumulation. Ions of calcium and copper compete for binding sites in gills and other organs (Lloyd, 1992), so when analyzing copper in tissue of fish from water with high concentration of calcium, the levels of this metal might be decreased (Birungi et al., 2007). Also, in alkaline conditions, copper precipitates as the carbonate and it is non toxic (Dallas \& Day, 1993), so pH might also have a role, making copper biologically unavailable (Birungi et al., 2007). Concerning manganese, a competition between manganese and calcium ions also occurs, thus decreasing the bioavailability of manganese to fish (Seymore et al., 1995; Birungi et al., 2007).

Zinc has the ability to bind to metallothioneins in the liver, but since copper has a greater affinity for proteins, zinc concentration might be low due to the presence of copper (Roch et al., 1985). pH might also affect concentration of soluble zinc, where high concentrations of this metal are found in well oxidized conditions ( $\mathrm{pH} 5$ to 6.5), whereas low concentrations might be observed in redox conditions ( $\mathrm{pH} 8)$ (Gambrell et al., 1991).

Concerning PAH accumulation, some studies have indicated that the PAH metabolite levels in bile might be highly influenced by the feeding status of the fish (Collier \& Varanasi, 1991; Brumley et al., 1998). An alternative used to reduce variations in $\mathrm{PAH}$ metabolite bile levels due to feeding status, is using procedures in which the metabolite concentrations are related to the biliary pigment contents or levels of total protein. In addition, PAH concentrations might be low due to the high metabolic rate in fish (Nesto et al., 2007).

\section{Metallothioneins (MTs)}

The correlation between MTs expression level and degree of pollution is particularly evident, confirming that their expression levels are influenced by various metals (Berthet $e t$ al., 2005; Sinaie et al., 2010). Consequently, this biomarker has been used in several studies in order to evaluate metal exposure (Nesto et al., 2007; Linde-Arias et al., 2008b; Fonseca et al., 2011; Jolly et al., 2012; Tomasello et al., 2012; Fasulo et al., 2013; Falfushynska et al., 2014). Nevertheless, confounding factors such as seasonal variation, age, reproductive status, water temperature, tissue and individual variation, could contribute to MTs expression modulation, interacting with each other or acting all together (Rhee et al., 2009; Shariati \& Shariati, 2011).

Among these factors, temperature is well known to modulate the aquatics specimens' sensitivity to metals by affecting physiological tolerance, energy demand and oxygen supply and/or mitochondrial biogenesis (Sokolova \& Lanning, 2008). Siscar et al. (2014) have observed a significant effect of temperature on MT content in the liver of Solea senegalensis.

Moreover, it has been hypothesized that the presence of organic contaminants reduces MTs synthesis by increasing the demand for cysteine residues of glutathione (GSH), a very important cellular antioxidant molecule (van der Oost et al., 2003). Low MT levels have been observed in sites with low metal contamination, but also in polluted sites characterized by metals contamination, petroleum/crude hydrocarbon inputs and combustion PAH sources (Fonseca et al., 2011). Thus, it demonstrates the ability of organic contaminants in reducing MT levels even in metal contaminated areas.

Furthermore, there is an existing variation in MTs expression among tissues. A higher expression has been found in muscle than in the liver. This could be due to the lower metal-binding capacity (metal uptake and/or accumulation) of the liver in respect to the muscle, a distorted mechanism of membrane transport and an altered mitochondrial biogenesis with consequent reduced energy power or oxygen supply, all induced by metal intoxication (van der Oost et al., 2003). Comparing MT expression in liver and gills, increased levels of MT have been found in gills and it could be attributed to the fact that this organ is the first route of metal uptake (Carvalho et al., 2012). The gills are more susceptible to the immediate (acute) effects of exposure to waterborne contaminants and livers are subjected to the more prolonged (chronic) effects of accumulated contaminants (Cerqueira \& Fernandes 2002).

Hormones have also been shown to influence MT levels. In female fish, $17 \beta$-estradiol indirectly inhibits MT by altering the zinc utilization in the liver during vitellogenesis (Gerpe et al., 2000).

\section{Biotransformation enzymes}

The first stage of detoxification of xenobiotics involves enzymatic transformation of a chemically modifying lipid soluble toxin into water-soluble toxin. Most of the transformation reactions in this phase involve a broad family of enzymes, cytochrome P450s (Lardone et al., 2010). The ethoxyresorufin O-deethylase (EROD) activity is considered a sensitive catalytic probe for determining the induction of the cytochrome $\mathrm{P} 450$ system in fish by micro-organic pollutants, 
particularly PCBs (van der Oost et al., 2003). Its activity is also considered a specific biomarker of PAH-like compounds exposure (Fonseca et al., 2011). EROD activity induction may be inhibited by estradiol, a hormone produced by mature females (Förlin \& Andersson, 1984). Therefore, higher levels of EROD response can be explained by the negative effect of endogenous estradiol on cytochrome P-450 catalytic activity (Arukwe \& Gokoyr, 1997). Consequently, this effect is more pronounced during breeding periods. This effect has been reported by some authors (Wunderlich et al., 2015). Another possibility for EROD inhibition in some fish species is the presence of trace metals, as demonstrated in some studies (Roméo et al., 1994; Guilherme et al., 2008; Vieira et al., 2009). Copper and cadmium have been shown to completely suppress EROD activity in the liver of Trematomus bernacchii (Benedetti et al., 2007). Moreover, the age has also been shown to influence EROD enzyme activity in fish (Whyte et al., 2000; van der Oost et al., 2003; Kashiwada et al., 2007). The influence of age on biomarker response to toxicants is partly the consequence of differences in uptake of contaminants through the life history stage such as larvae, embryos, juveniles and adults (Amiard-Triquet et al., 2013). Furthermore, EROD activity can also be influenced by water temperature (Andersson \& Förlin, 1992).

The toxicity of many exogenous compounds can be modulated by induction of phase II biotransformation enzymes, as glutathione S-transferase (GST) (van der Oost et al., 2003). The phase II enzymes modify phase I products into more water-soluble and less toxic forms (Hassan et al., 2015). As EROD, GST activity seems to be correlated to spawning period presenting lower values (Jolly et al., 2012). Nevertheless, the involved mechanisms are not clear. Previous studies have described a bell-shaped pattern in GST activity for different species, where the enzyme activity increases with increasing contaminant exposure until a certain concentration where enzymatic activity progressively decreases (Elia et al., 2003; Vieira et al., 2009). Moreover, both GST inhibition and induction after exposure to different PAH and metals have been reported (Sanchez et al., 2005; Vieira et al., 2009).

A clear gender and seasonal effect has been observed for the biotransformation enzymes described above (EROD and GST), with higher values in male fish compared to females, whereas a decrease in these enzymes has been reported in the bullhead (Cottus sp) collected in the summer (Jolly et al., 2012).

\section{Antioxidant enzymes}

Many pollutants (or their metabolites) may exert toxicity through oxidative stress. Oxidative stress occurs when the rate of reactive oxygen species (ROS) exceeds the antioxidant defense system. Oxidative stress can derive from increased production of ROS mediated by heavy metals and numerous organic contaminants, including redox cycling compounds, PAHs, halogenated hydrocarbons and dioxins (Livingstone, 2001).

Antioxidant enzymes are commonly employed as biomarkers of oxidative stress; however, responses to pollution vary from different species, enzymes, and single or mixed contaminants, and even greater variability is found in field situations (Livingstone, 2001). In highly polluted sites, antioxidant enzymes responses can either be induced or inhibited depending on some factors (Fonseca et al., 2011). Habitat, feeding behavior, nutritional status, age and other nonchemical factors have been reported to influence in fish oxidative stress, as well as its antioxidant potential (Ameur et al., 2012; Hook et al., 2014).

Similarly to GST, the enzyme responses to toxic chemicals shows a bell-shaped dose-response curve, with an initial increase in activity due to enhanced catabolic rate and/or direct inhibition by toxic chemicals (Viarengo et al., 2007; Marigomez et al., 2013). This should be taken into account when designing field experiments (Hook et al., 2014).

The reduced activity of superoxide dismutase (SOD) and catalase (CAT) may be attributed to long term exposure of fish to environmental pollutants and a similar type of response has been demonstrated (Bainy et al., 1996; Lenartova et al., 1997). Furthermore, herbivorous fish species have higher SOD activities than omnivorous fish (Radi et al., 1985). Dietary levels of lipids and some vitamins have been reported to influence antioxidant defenses and oxidative status of fish (Ameur et al., 2012). Diets containing oxidized oil significantly affected the activities of liver antioxidant defense enzymes of gilthead sea bream (Sparus aurata L.) and dietary vitamin E partially abrogated these effects (Mourente et al., 2002). In another study, activity levels of the antioxidant enzymes CAT and SOD were higher in livers of fish fed with a high lipid level (Rueda-Jasso et al., 2004).

A seasonal variation has been observed for glutathione peroxidase (GPx) activity. This pattern could be observed in a few studies (Sanchez et al., 2007; Jolly et al., 2012), where fish collected in the summer, presented higher GPx activity compared to other seasons, and this could be explained by the involvement of GPx in steroid metabolism (Sanchez et al., 2007).

\section{Cholinesterase (ChE) activity}

Among ChE, the acetylcholinesterase (AChE) is the most important, which is found in the nervous tissue and is highly specific to the neurotransmitter acetylcholine (Fulton \& Key, 2001; Domingues et al., 2010). AChE removes acetylcholine from the synapses, thus regulating the transmission impulses. Inhibition of $\mathrm{AChE}$ in the nervous system results in the accumulation of acetylcholine at toxic levels (Domingues et al., 2010). This results in a larger residence time of the neurotransmitter at the cholinergic receptor, leading to hyperexcitation and death (Printes et al., 2011).

AChE inhibition in many species persists for much longer than pesticide concentration in environmental samples, therefore offering advantage over the use of analytical chemistry alone (Fulton \& Key, 2001). Several studies have used this biomarker to evaluate exposure of fish to 
organophosphate and carbamate pesticides (Linde-Arias et al., 2008b; Kopecka \& Pempkowiak, 2008; Printes et al., 2011; Jolly et al., 2012; Bueno-Krawczyk et al., 2015; Vieira et al., 2016), where its activity is usually decreased. Nevertheless, metallic ions such as arsenic, copper and mercury have shown to inhibit AChE activity as well (Lagadic et al., 1994). Detergents can also lead to AChE inhibition (Guilhermino et al., 1998). High and low AChE activity has been recorded in pesticide polluted sites, reflecting a seasonal variation (Jolly et al., 2012).

A variation in $\mathrm{AChE}$ activity has also been attributed to water temperature (Napierska \& Podolska, 2005; Kopecka \& Pempkowiak, 2008), since it is known that temperature can affect the physiological activity of fish (Bocquenè et al., 1990). However, there are conflicting data in the literature, since some studies have reported a negative relationship between AChE activity and increased temperature in fish (Botté et al., 2013), a positive effect of temperature (Pfeifer et al., 2005; Durieux et al., 2011) or no significant effect (Beauvais et al., 2002; Phillips et al., 2002).

\section{Lipid peroxidation (LPO)}

Lipid peroxidation is a well-known mechanism of cell injury in vertebrates and invertebrates, being an indicator of an oxidative damage in cells and tissues. Therefore, measurement of malondialdehyde (MDA), the end product of lipid peroxidation is widely used as an indicator of lipid peroxidation (Wheatley, 2000; Fonseca et al., 2011).

Several studies have shown enhanced LPO in aquatic organisms exposed to high concentrations of metals (Ahmad et al., 2000; Oakes \& Kraak, 2003; Pandey et al., 2008; Ruas et al., 2008; Monteiro et al., 2010; Carvalho et al., 2012). Nevertheless, low levels of LPO might be a reflection of feeding habitat and not pollution per se, since it has been shown that LPO tends to be lower in herbivorous fish than in omnivorous fish species (Radi et al., 1985).

\section{Heat Shock Protein 70 (HSP70)}

HSPs, a family of ubiquitous proteins, are considered the first line of defense following exposure from high temperatures and many other stressors, including xenobiotics and contaminants. Therefore, they are commonly accepted as biochemical indicators of toxicity index, providing a measure of proteotoxicity of pollutants (Kohler et al., 2001; Padmini \& Usha Rani, 2008), and thus, this biomarker has been used in some studies (Webb \& Gagnon, 2009; Tomasello et al., 2012; Fasulo et al., 2013). The un-modulated expression of HSP70 might be the result of a suppression of the cytoprotective upregulation of molecular chaperone due to either simultaneous exposure to different stressors or high concentrations of pollutants (Ivanina et al., 2009). The HSP70 decrease at high metal concentration might also be attributed to pathological damage and inhibition of protein synthesis in the cell (Clayton et al., 2000; Ivanina et al., 2009).
Although these proteins are involved in the protection and repair of the cell response to xenobiotics and contaminants exposure, it is important to consider their role in conditions such as high or low temperature, ultraviolet light, oxidative conditions, anoxia, and so forth (Stegeman et al., 1992; Di Giulio et al., 1995). It has been reported that HSP70 induction is more suitable as a biomarker of exposure at low temperatures (Triebskorn et al., 1997). Therefore, since nutrition and water quality ( $\mathrm{pH}$, temperature, salinity and dissolved oxygen) can affect this protein response, these factors should be considered during monitoring (van der Oost et al., 2003). This biomarker has not been used as much as others in studies over the past years probably because of the difficulty in the interpretation of HPS70 response.

\section{Ecological indexes}

Some authors have proposed the use of ecological indexes like gonadosomatic index and condition factor in biomonitoring studies to evaluate the influence of biotic processes or as an additional tool in biomonitoring approaches (Adams \& Ryon, 1994), since these indexes are easily obtained. Condition factor values represent a gross index and reflect the condition of the whole body. It is usually related to food quality (Bagnasco et al., 1991). Although it has been used by researchers to provide information on potential pollution impacts (Linde-Arias et al., 2008a; Jolly et al., 2012; Procópio et al., 2014; BuenoKrawczyk et al., 2015; Ossana et al., 2016), this parameter is not very sensitive and may be affected by non-pollutant factors, such as season, disease and nutritional levels (Mayer et al., 1992). High condition factor values have been found in fish captured in an untreated-domestic-sewage-polluted site (Alberto et al., 2005), whereas no differences were observed in fish exposed to agricultural and urban pressures (Jolly et al., 2012).

Reproductive status is highlighted by the highest gonadosomatic index (GSI). Pollutant concentrations and biological responses showed strong seasonal variations in both mussels and fish, generally related to cyclic physiological changes linked to reproduction and food availability. These results stress the need for careful evaluation of the biological cycles of selected sentinel organisms before planning biomonitoring surveys (Nesto et al., 2007).

\section{CONCLUSION}

The use of biomarkers is essential for assessing aquatic ecosystems health. As evidenced in this review, there are some confounding factors that might affect biomarker responses, such as age, gender, feeding habitat and temperature. However, non-pollutant factors are usually only mentioned in the literature; thus, obtaining quantitative data on the extent of the interference of a give nonpollutant factor on biomarker response could contribute to environmental diagnosis. A multibiomarker approach is strongly recommended to reduce data misinterpretation, since 
one single biomarker cannot provide a reliable diagnosis of environmental degradation. Furthermore, researchers should also consider the use of unpolluted sites as control areas and collect fish in different periods to monitor possible seasonal variations. The combination of biomarkers with water and sediment physicochemical analysis is also recommended. In this context, laboratory experiments are also invaluable in order to investigate the physiology of a specie to be used as bioindicator in field conditions and mechanisms of toxicity of some substances.

\section{REFERENCES}

ADAMS, S.M., GIESY, J.P., TREMBLAY, L.A. \& EASON, C.T. 2001. The use of biomarkers in ecological risk assessment: recommendations from the Christchurch conference on Biomarkers in Ecotoxicology. Biomarkers 6: 1-6. http://dx.doi. org/10.1080/135475001452724.

ADAMS, S.M. \& RYON, M.G. 1994. A comparison of health assessment approaches for evaluating the effects of contaminatedrelated stress on fish populations. J. Aquat. Ecosyst. Health 3: 1525. http://dx.doi.org/10.1007/BF00045153.

AHMAD, I., HAMID, T., FATIMA, M., CHAND, HS., JAIN, S.K., ATHAR, M. \& RAISUDDIN, S. 2000. Induction of hepatic antioxidant in freshwater catfish (Channa punctatus Bloch) is a biomarker of paper mill effluent exposure. Biochim. Biphys. Acta 1523(1): 37-48. http://dx.doi.org/10.1016/S03044165(00)00098-2.

ALBERTO, A., CAMARGO, A.F.M., VERANI, J.R., COSTA, O.F.T. \& FERNANDES, M.N. 2005. Health variables and gill morphology in the tropical fish Astyanax fasciatus from a sewage-contaminated river. Ecotox. Environ. Safe. 61: 247-255. http://dx.doi.org/10.1016/j.ecoenv.2004.08.009.

AMEUR, W.B., LAPUENTE, J., EL MEGDICHE, Y., BARHOUMI, B., TRABELSI, S., CAMPS, L., SERRET, J., RAMOS-LÓPEZ, D., GONZALEZ-LINARES, J., DRISS, M.R. \& BORRÀS, M. 2012. Oxidative stress, genotoxicity and histopathology biomarker responses in mullet (Mugil cephalus) and sea bass (Dicentrarchus labrax) liver from Bizerte Lagoon (Tunisia). Mar. Pollut. Bull. 64:241-251. http://dx.doi.org/10.1016/j. marpolbul.2011.11.026.

AMIARD-TRIQUET, C., AMIARD, J.C. \& RAINBOW, P.S. 2013. Ecological Biomarkers: Indicators of Ecotoxicological Effects. CRC Press, Taylor \& Francis Group, Boca Raton, FL.

ANDERSSON, T. \& FÖRLIN, L. 1992. Regulation of cytochrome P450 enzyme system in fish. Aquat. Toxicol. 24:1-20. http:// dx.doi.org/10.1016/0166-445X(92)90014-E.

ARUKWE, A. \& GOKOYR, A. 1997. Changes in three hepatic cytochrome P450 subfamilies during a reproductive cycle in turbot (Scophthalmus maximus L.). J. Exp. Zool. 277: 313-325.

BAGNASCO, M., CAMOIRANO, A., DE FLORA, S., MELODIA, F. \& ARILLO, A. 1991. Enhanced liver metabolism of mutagens and carcinogens in fish living in polluted seawater. Mut. Res. 262: 129-137. http://dx.doi.org/10.1016/0165-7992(91)90119-O.

BAINY, A.C.D., SAITO, E., CARVALHO, P.S.M. \& JUNQUEIRA, V.B.C. 1996. Oxidative stress in Gill, erythrocytes, liver and kidney of Nile tilapia (Oreochromis niloticus) from a polluted site. Aquat. Toxicol. 34: 151-162. http://dx.doi.org/10.1016/0166445X(95)00036-4.

BEAUVAIS, S.L., COLE, K.J., ATCHISON, G.J. \& COFFEY, M. 2002. Factors affecting brain cholinesterase activity in bluegill (Lepomis macrochirus). Water Air Soil Pollut. 135:249-264.
http://dx.doi.org/10.1023/A:1014778109657.

BENEDETTI, M., MARTUCCIO, G., FATTORINI, D., CANAPA, A., BARUCCA, M., NIGRO, M. \& REGOLI, F. 2007. Oxidative and modulatory effects of trace metals on metabolismo $\mathrm{f}$ polycyclic aromatic hydrocarbons in the Antarctic fish Trematomus bernacchii. Aquat. Toxicol. 85: 167-175.

BERTHET, B., MOUNEYRAC, C., PEREZ, T. \& AMIARDTRIQUET, C. 2005. Metallothionein concentration in sponges (Spongia officinalis) as a biomarker of metal contamination. Comp. Biochem. Physiol. C 141: 306-313. http://dx.doi. org/10.1016/j.cca.2005.07.008.

BIRUNGI, Z., MASOLA, B., ZARANYIKA, M.F., NAIGAGA, I. \& MARSHALL, B. 2007. Active biomonitoring of trace heavy metals using fish (Oreochromis niloticus) as bioindicator species. The case of Nakivubo wetland along Lake Victoria. Phys. Chem. Earth 32: 1350-1358. http://dx.doi.org/10.1016/j. pce.2007.07.034.

BOCQUENÈ, G., GALGANI, F. \& TRUQUET, P. 1990 Characterization and assay conditions for use of AChE activity from several marine species in pollution monitoring. Mar. Environ. Res. 30: 75-89. http://dx.doi.org/10.1016/01411136(90)90012-D.

BOTTÉ, E.S., SMITH-KEUNE, C. \& JERRY, D.R. 2013. Temperature: a prolonged confounding factor on cholinesterase activity in the tropical reef fish Acanthochromis polyacanthus. Aquat. Toxicol.http://dx.doi.org/10.1016/j.aquatox.2013.06.021.

BRUMLEY, C.M., HARITOS, V.S., AHOKAS, J.T. \& HOLDWAY, D.A. 1998. The effects of exposure duration and feeding status on fish bile metabolites: implications for biomonitoring. Ecotoxicol. Environ. Safe. 39: 147-153. http://dx.doi.org/10.1006/ eesa.1997.1622.

BUENO-KRAWCZYK, A.C.D., GUILOSKI, I.C., PIANCINI, L.D.S., AZEVEDO, J.C., RAMSDORF, W.A., IDE, A.H., GUIMARÃES, A.T.B., CESTARI, M.M. \& SILVA DE ASSIS, H.C. 2015. Multibiomarker in fish to evaluate a river used to water public supply. Chemosphere 135:257-264. http://dx.doi. org/10.1016/j.chemosphere.2015.04.064.

CARVALHO, C.S., BERNUSSO, V.A., ARAÚJO, H.S.S., ESPÍNDOLA, E.L.G. \& FERNANDES, M.N. 2012. Biomarker responses as indicator of contaminant effects in Oreochromis niloticus. Chemosphere 89: 60-69. http://dx.doi.org/10.1016/j. chemosphere.2012.04.013.

CERQUEIRA, C.C. \& FERNANDES, M.N. 2002. Gill tissue recovery after copper exposure and blood parameter responses in the tropical fish Prochilodus scrofa. Ecotoxicol. Environ. Safe. 52: 83-91. http://dx.doi.org/10.1006/eesa.2002.2164.

CLAYTON, M., STEINMANN, R. \& FENT, K. 2000. Different expression patterns of heat shock proteins hsp 60 and hsp 70 in zebra mussels (Dreissena polymorpha) exposed to copper and tributyltin. Aquat. Toxicol. 47: 213-226. http://dx.doi. org/10.1016/S0166-445X(99)00022-3.

COLLIER, T.K. \& VARANASI, U. 1991. Hepatic activities of xenobiotic metabolizing enzymes and biliary levels of xenobiotics in English sole (Parophrys vetulus) exposed to environmental contaminants. Arch. Environ. Con. Tox. 20: 462473. http://dx.doi.org/10.1007/BF01065834.

CROTEAU, M.N., LUOMA, S.N. \& STEWART, A.R. 2005. Trophic transfer of metals along freshwater food web: evidence of cadmium biomagnifications in nature. Limnol. Oceanogr. 50(5): 1511-1519. http://dx.doi.org/10.4319/lo.2005.50.5.1511.

DALLAS, H.F. \& DAY, J.A. 1993. The effect of water quality variables on riverine ecosystems: a review. Fresh Water Research Unit, University of Cape Town, Rondebosch, South Africa.

DEPLEDGE, M.H. \& FOSSI, M.C. 1994. The role of biomarkers in environmental assessment (2). Invertebrates. Ecotoxicol. 3: 161172. . http://dx.doi.org/10.1007/BF00117081.

DI GIULIO, R.T., BENSON, W.H., SANDERS, B.M. \& VAN 
VELD, P.A. 1995. Biochemical mechanisms: metabolism, adaptation, and toxicity. In: Rand, G.M. (Ed.), Fundamentals of Aquatic Toxicology: Effects, Environmental fate, and Risk Assessment, second ed. Taylor and Francis, London, UK, pp. 523-562.

DOMINGUES, I., AGRA, A.R., MONAGHAN, K., SOARES, A.M.V.M. \& NOGEIRA, A.J.A. 2010. Cholinesterase and glutathione S-transferase activities in freshwater invertebrates as biomarkers to assess pesticide contamination. Environ. Toxicol. Chem. 29: 5-18. http://dx.doi.org/10.1002/etc.23.

DURIEUX, E.H., FARVER, T., FITZGERALD, P., EDER, K. \& OSTRACH, D. 2011. Natural factors to consider when using acetylcholinesterase activity as neurotoxicity biomarker in Young-Of-Year striped bass (Morone saxatilis). Fish Physiol. Biochem. 37:21-29. http://dx.doi.org/10.1007/s10695-0109412-9.

ELIA, A.C., GALARINI, R., TATICCHI, M.I., DORR, A.J. \& MANTILACCI, L. 2003. Antioxidant responses and bioaccumulation in Ictalurus melas under Mercury exposure. Ecotoxicol. Environ. Safe. 55: 162-167. http://dx.doi. org/10.1016/S0147-6513(02)00123-9.

FALFUSHYNSKA, H., GNATYSHYNA, L., TURTA, O., STOLIAR, O., MITINA, N., ZAICHENKO, A. \& STOIKA, R. 2014. Responses of hepatic metallothioneins and apoptotic activity in Carassius auratus gibelio witness a release of cobalt and zinc from waterborne nanoscale composites. Comp. Biochem. Phys. C. 160:66-74. http://dx.doi.org/10.1016/j. cbpc.2013.11.009.

FASULO, S., MAUCERI, A., MAISANO, M., GIANNETOO, A., PARRINO, V., GENNUSO, F., D'AGATA, A. 2013. Immunohistochemical and molecular biomarkers in Coris julis exposed to environmental contaminants. Ecotoxicol. Environ. Safe. 73(5): 873-882. http://dx.doi.org/10.1016/j. ecoenv.2009.12.025.

FONSECA, V.F., FRANÇA, S., SERAFIM, A., COMPANY, R., LOPES, B., BEBIANNO, M.J., CABRAL, H.N. 2011. Multibiomarker responses to estuarine habitat contamination in three fish species: Dicentrarchus labrax, Solea senegalensis and Pomatoschistus microps. Aquat. Toxicol. 102: 216-227. http:// dx.doi.org/10.1016/j.aquatox.2011.01.018.

FÖRLIN, L. \& ANDERSSON, T. 1984. Influence of biological and environmental factors on hepatic steroid and xenobiotic metabolism in fish: interaction with PCB and $\beta$-naphthoflavone. Mar. Environ. Res. 14: 47-58. http://dx.doi.org/10.1016/01411136(84)90069-2.

FULTON, M.H. \& KEY, P.B. 2001. Acetylcholinesterase inhibition in estuarine fish and invertebrates as an indicator of organophosphorous insecticide exposure and effects. Environ. Toxicol. Chem. 20: 37-45. http://dx.doi.org/10.1002/ etc. 5620200104.

GAMBRELL, R.P., WIESEPAPE, J.B., PATRICK, W.H. \& DUFF, M.C. 1991. The effect of $\mathrm{pH}$, redox, and salinity on metal release from a contaminated sediment. Water Air Soil Poll. 57-58(1): 359-367. http://dx.doi.org/10.1007/BF00282899.

GERPE, M., KLING, P., BERG, A.H. \& OLSSON, P.E. 2000. Arctic char (Salvelinus alpinus) metallothionein: cDNA sequence, expression, and tissue-specific inhibition of cadmium-mediated metallothionein induction by 17ß-estradiol, 4-OH-PCB 30, and PCB 104. Environ. Toxicol. Chem. 19(3): 638-645. http://dx.doi. org/10.1002/etc.5620190316.

GUILHERME, S., VÁLEGA, M., PEREIRA, M.E., SANTOS, M.A. \& PACHECO, M. 2008. Antioxidant and biotransformation responses in Liza aurata under environmental Mercury exposure - relationship with Mercury accumulation and implications for public health. Mar. Pollut. Bull. 56: 845-859. http://dx.doi. org/10.1016/j.marpolbul.2008.02.003.

GUILHERMINO, L., BARROS, P., SILVA, M.C. \& SOARES, A.M.V.M. 1998. Should the use of inhibition of cholinesterases as a specific biomarker of organophosphate and carbamate be questioned? Biomarkers 3: 157-163. http://dx.doi. org/10.1080/135475098231318.

HASSAN, I., JABIR, N.R., AHMAD, S., SHAH, A. \& TABREZ, S. 2015. Certain phase I and II enzymes as toxicity biomarker: an overview. Water Air Soil Poll. 226:153. http://dx.doi. org/10.1007/s11270-015-2429-z.

HELLOU, J. 2011. Behavioural ecotoxicology, an "early warning" signal to assess environmental quality. Environ. Sci. Pollut. R18: 1-11. http://dx.doi.org/10.1007/s11356-010-0367-2.

HOOK, S.E., GALLAGHER, E.P. \& BATLEY, G.E. 2014. The role of biomarkers in the assessment of aquatic ecosystem health. Integr. Environ. Assess. Manag. 10(3):327-341. http://dx.doi. org/10.1002/ieam.1530.

IVANINA, A.V., TAYLOR, C. \& SOKOLOVA, I.M. 2009. Effects of elevated temperature and cadmium exposure on stress protein response in eastern oysters Crassostrea virginica (Gmelin). Aquat. Toxicol. 91: 245-254. http://dx.doi.org/10.1016/j. aquatox.2008.11.016.

JOLLY, S., BADO-NILLES, A., LAMAND, F., TURIES, C., CHADILI, E., PORCHER, J.M., BETOULLE, S. \& SANCHEZ, W. 2012. Multi-biomarker approach in wild European bullhead, Cottus sp., exposed to agricultural and urban environmental pressures: Practical recommendations for experimental design. Chemosphere 87: 675-683. http://dx.doi.org/10.1016/j. chemosphere.2011.12.055.

KASHIWADA, S., GOKA, K., SHIRAISHI, H., ARIZONO, K., OZATO, K., WAKAMATSU, Y. \& HINTON, D.E. 2007. Age-dependent in situ hepatic and gill CYP1A activity in the seethrough medaka (Oryzias latipes). Comp. Biochem. Physiol. C Toxicol. Pharmacol. 145:96-102. http://dx.doi.org/10.1016/j. cbpc.2006.07.005

KOHLER, H.R., BARTUSSEK, C., ECKWERT, H., FARIAN, K., GRANZER, S., KNIGGE, T. \& KINZ, N. 2001. The hepatic stress protein (hsp70) response to interacting abiotic parameters in fish exposed to various levels of pollution. J. Aquat. Ecosystem. Stress Recovery 8: 261-279. http://dx.doi. org/10.1023/A:1012935931161.

KOPECKA, J. \& PEMPKOWIAK, J. 2008. Temporal and spatial variations of selected biomarker activities in flounder (Platichthys flesus) collected in Baltic proper. Ecotoxicol. Environ. Safe. 70: 379-391. http://dx.doi.org/10.1016/j.ecoenv.2007.05.017.

LAGADIC, L., CAQUET, T. \& RAMADE, F. 1994. The role of biomarkers in environmental risk assessment (5). Invertebrate populations and communities. Ecotoxicol. 3: 193-208. http:// dx.doi.org/10.1007/BF00117084.

LARDONE, M.C., CASTILlO, P., VALDEVENITO, R., EBENSPERGER, M., RONCO, A.M., POMMER, R., PIOTTANTE, A. \& CASTRO, A. 2015. P450-aromatase activity and expression in human testicular tissues with severe spermatogenic failure. Int. J. Androl. 33(4):650-660. http://10.1111/j.1365-2605.2009.01002.x.

LENARTOVA, V., HOLOVSKA, K., PEDRAJAS, J.R., LARA, E.M., PEINADO, J., BAREA, J.L., ROSIVAL, I. \& KOSUTH, P. 1997. Antioxidant and detoxifying fish enzymes as biomarkers of river pollution. Biomarkers 2: 247-252. http://dx.doi. org/10.1080/135475097231625.

LINDE-ARIAS, A.R., INÁCIO, A.F., NOVO, L.A., ALBURQUERQUE, C., FREIRE, M.M. \& MOREIRA, J.C. 2008a. Biomarkers in an invasive fish species, Oreochromis 
niloticus, to assess the effects of pollution in a highly degraded Brazilian River. Sci. Total Environ. 399: 186-192. http://dx.doi. org/10.1016/j.scitotenv.2008.03.028.

LINDE-ARIAS, A.R., INÁCIO, A.F., NOVO, L.A., ALBURQUERQUE, C. \& MOREIRA, J.C. $2008 \mathrm{~b}$. Multibiomarker approach in fish to assess the impact of pollution in a large Brazilian river, Paraiba do Sul. Environ. Pollut. 156, 974-979. http://dx.doi.org/10.1016/j.envpol.2008.05.006.

LLOYD, R. 1992. Pollution and Fresh Water Fish. Blackwell Scientific Publications Ltd., England.

LIVINGSTONE, D.R. 2001. Contaminant-stimulated reactive oxygen species production and oxidative damage in aquatic organisms. Mar. Pollut. Bull. 42: 656-666. http://dx.doi. org/10.1016/S0025-326X(01)00060-1.

MARIGOMEZ, I., ZORITA, I., IZAGUIRRE, U., ORTIZZARRAGOITIA, M., NAVARRO., P., ETXEBARRIA, N., ORBEA, A., SOTO, M. \& CAJARAVILLE, M.P. 2013. Combined use of native and caged mussels to assess biological effects of pollution through the integrative biomarker approach. Aquat. Toxic. 136-137:32-48. http://dx.doi.org/ 10.1016/j. aquatox.2013.03.008.

MAYER, F.L., VERSTEEG, D.J., MCKEE, M.J., FOLMAR, L.C., GRANEY, R.L., MCCUME, D.C. \& RATTNER, B.A. 1992. Metabolic products as biomarkers. In: HUGGETT, R.J., KIMERLY, R.A., MEHRLE, JR P.M. \& BERGMAN, H.L. (Eds), Biomarkers: Biochemical, Physiological and Histological Markers of Anthropogenic Stress. Lewis Publishers, Chelsea, MI, USA, pp. 5-86.

MCGLASHAN, D.J. \& HUGHIES, J.M. 2001. Genetic evidence for historical continuity between populations of the Australian freshwater fish Craterocephalus stercusmuscarum (Atherinidae) east and west of the Great Diving Range. J. Fish Biol. 59: 55-67. http://dx.doi.org/10.1111/j.1095-8649.2001.tb01378.x.

MONTEIRO, D.A., RANTIN, F.T. \& KALININ, A.L. 2010. Inorganic mercury exposure: toxicological effects, oxidative stress biomarkers and bioaccumulation in the tropical freshwater fish matrinxã, Brycon amazonicus (Spix and Agassiz, 1829). Ecotoxicol. 19: 105-123. http://dx.doi.org/10.1007/s10646-0090395-1.

MOURENTE, G., DÍAZ-SALVAGO, E., BELL, J.G. \& TOCHER, D.R. 2002. Increased activities of hepatic antioxidant defense enzymes in juvenile gilthead sea bream (Sparus aurata L.) fed dietary oxidized oil: attenuation by dietary vitamin E. Aquaculture 214: 343-361. http://dx.doi.org/10.1016/S00448486(02)00064-9.

NAPIERSKA, D. \& PODOLSKA, M. 2005. Biomarkers of contaminant exposure: results of a field study with flounder (Platichthys flesus) from the southern Baltic Sea. Mar. Pollut. Bull. 50: 758-767. http://dx.doi.org/10.1016/j. marpolbul.2005.02.007.

NESTO, N., ROMANO, S., MOSCHINO, V., MAURI, M. \& DA ROS, L. 2007. Bioaccumulation and biomarker responses of trace metals and micro-organic pollutants in mussels and fish from the Lagoon of Venice, Italy. Mar. Pollut. Bull. 55: 469-484. http://dx.doi.org/10.1016/j.marpolbul.2007.09.009.

OAKES, K.D. \& KRAAK, G.J.V.D. 2003. Utility of the TBARS assay in detecting oxidative stress in white sucker (Catostomus commersoni) populations exposed to pulp mill effluent. Aquat. Toxicol. 63: 447-463. http://dx.doi.org/10.1016/S0166445X(02)00204-7.

OSSANA, N.A., EISSA, B.L., BAUDOU, F.G., CASTAÑÉ, P.M., SOLONESKI, S. \& FERRARI, L. 2016. Multibiomarker response in tem spotted live-bearer fish Cnesterodon decemmaculatus (Jenyns, 1842) exposed to Reconquista river water. Ecotoxicol. Environ. Safe. 133:73-81. http://dx.doi. org/10.1016/j.ecoenv.2016.06.046.

PADMINI, E. \& USHA RANI, M. 2008. Impact of seasonal variation on HSP70 expression quantitated in stressed fish hepatocytes. Comp. Biochem. Physiol. B. 151: 278-285. http:// dx.doi.org/10.1016/j.cbpb.2008.07.011.

PANDEY, S., PARVEZ, S., ANSARI, R.A., ALI, M., KAUR, M., HAYAT, F., AHMAD, F. \& RAISUDDIN, S. 2008. Effects of exposure to multiple trace metals on biochemical, histological and ultrastructural features of gills of a freshwater fish, Channa punctata Bloch. Chem-Biol. Interact. 174: 183-192. http:// dx.doi.org/10.1016/j.cbi.2008.05.014.

PAULINO, M.G., BENZE, T.P., SADAUSKAS-HENRIQUE, H., SAKURAGUI, M.M., FERNANDES, J.B. \& FERNANDES, M.N. 2014. The impact of organochlorines and metals on wild fish living in a tropical hydroelectric reservoir: bioaccumulation and histopathological biomarkers. Sci. Total Environ. 497498:293-306. http://dx.doi.org/10.1016/j.scitotenv.2014.07.122.

PFEIFER, S., SCHIEDEK, D. \& DIPPNER, J.W. 2005. Effect of temperature and salinity on acetylcholinesterase activity, a common pollution biomarker, in Mytilus sp. from the southwestern Baltic Sea. J. Exp. Marine Biol. Ecol. 320:93-103. http:// dx.doi.org/10.1016/j.jembe.2004.12.020.

PHILLIPS, T.A., SUMMERFELT, R.C. \& ATCHISON, G.J. 2002. Environmental, biological, and methodological factors affecting cholinesterase activity in walleye (Stizostedion vitreum). Arch. Environ. Com. Toxicol. 43:75-80. http://dx.doi.org/10.1007/ s00244-002-1134-2.

PRINTES, L.B., FERNANDES, M.N. \& ESPÍNDOLA, E.L.G. 2011. Laboratory measurements of biomarkers and individual performances in Chironomus Xanthus to evaluate pesticide contamination of sediments in a river of southern Brazil. Ecotoxicol. Environ. Safe. 74: 424-430. http://dx.doi. org/10.1016/j.ecoenv.2010.10.033.

PROCÓPIO, M.S., RIBEIRO, H.J., PEREIRA, L.A., LOPES, G.A.O., CASTRO, A.C.S., RIZZO, E., SATO, Y., RUSSO, R.C. \& JUNIOR, J.D.C. 2014. Sex-response differences of immunological and histopathological biomarkers in gills of Prochilodus argenteus from a polluted river in southeast Brazil. Fish Shellfish Immun. 39:108-117. http://dx.doi.org/10.1016/j. fsi.2014.04.010.

RADI, A.A.R., HAI, D.Q., MATKOVICS, B. \& GABRIELAK, T. 1985. Comparative antioxidant enzyme study in freshwater fish with different types of feeding behavior. Comp. Biochem. Physiol. C 81: 395-399. http://dx.doi.org/10.1016/07428413(85)90026-X.

RHEE, J.S., RAISUDDIN, S., HWANG, D.S., LEE, K.W., KIM, I.C. \& LEE, J.S. 2009. Differential expression of metallothionein (MT) gene by trace metals and endocrine-disrupting chemicals in the hermaphroditic mangrove killifish, Kryptolebias marmoratus. Ecotoxicol. Environ. Safe. 72:206-212. http:// dx.doi.org/: 10.1016/j.ecoenv.2008.06.001.

ROCH, M., NORDIN, R.N., AUSTIN, A., MCKEAN, C.P.J., DENISEGER, J., KATHMAN, R.D., MCCARTER, J.A. \& CLARK, M.J.R. 1985. The effects of heavy metal contamination on the aquatic biota of Buttle Lake and Campbell river drainage (Canada). Arch. Environ. Con. Toxicol. 14: 347-362. http:// dx.doi.org/10.1007/BF01055412.

ROMÉO, M., MATHIEU, A., GNASSIA-BARELLI, M., ROMANA, A. \& LAFAURIE, M. 1994. Heavy metal content and biotransformation enzymes in two fish species from NW Mediterranean. Mar. Ecol. Prog. Ser. 107: 15-22.

RUAS, C.B.G., CARVALHO, C.S., ARAÚJO, H.S.S., ESPÍNDOLA, E.L.G. \& FERNANDES, M.N. 2008. Oxidative 
stress biomarkers of exposure in the blood of three cichlid species from a polluted river. Ecotoxicol. Environ. Safe. 71: 8693. http://dx.doi.org/10.1016/j.ecoenv.2007.08.018.

RUEDA-JASSO, R., CONCEICAO, L.E.C., DIAS, J., DE COEN, W., GOMES, E., REES, J.F., SOARES, F., DINIS, M.T. \& SORGELOOS, P. 2004. Effect of dietary non-protein energy levels on condition and oxidative status of Senegalese sole (Solea senegalensis) juveniles. Aquaculture 231: 417-433. http://dx.doi. org/10.1016/S0044-8486(03)00537-4.

SANCHEZ, W., AIT-AISSA, S., PALlUEL, O., DITCHE, J.M. \& PORCHER, J.M. 2007. Preliminary investigation of multibiomarker responses in three-spined stickleback (Gasterosteus aculeatus L.) sampled in contaminated streams. Ecotoxicol. 16: 279-287. http://dx.doi.org/10.1007/s10646-006-0131-z.

SANCHEZ, W., PALLUEL, O., MEUNIER, L., COQUERY, M., PORCHER, J.M. \& AÏT-AÏSSA, S. 2005. Copper-induced oxidative stress in three-spined stickleback: relationship with hepatic metal levels. Environ. Toxicol. Pharmacol. 19: 177-183. http://dx.doi.org/10.1016/j.etap.2004.07.003.

SEYMORE, T., DU PREEZ, H.H. \& CAN VUREN, J.H.J. 1995. Manganese, lead, and strontium bioaccumulation in the tissues of the yellow Barbus marequensis from the lower Olifants River, Eastern Transvaal Water, South Africa, pp 241-244.

SHARIATI, F. \& SHARIATI, S. 2011. Review on methods for determination of metallothioneins in aquatic organisms. Biol. Trace Elem. Res. 141: 340-366. http://dx.doi.org/ 10.1007/ s12011-010-8740-z.

SINAIE, M., BASTAMI, K.D., GHORBANPOUR, M., NAJAFZADEH, H., SHEKARI, M. \& HAGHPARAST, S. 2010. Metallothionein biosynthesis as a detoxification mechanism in mercury exposure in fish, spotted scat (Scatophagus argus). Fish Physiol. Biochem. 36: 1235-1242. http://dx.doi.org/ 10.1007/ s10695-010-9403-x.

SISCAR, R., TORREBLANCA, A., RAMO, J. \& SOLÉ, M. 2014. Modulation of metallothionein and metal partitioning in liver and kidney of Solea senegalensis after long-term acclimation to two environmental temperatures. Environ. Res. 132:197-205. http:// dx.doi.org/10.1016/j.envres.2014.04.020.

SOKOLOVA, I.M. \& LANNING, G. 2008. Interactive effects of metal pollution and temperature on metabolism in aquatic ectotherms: implications of global climate change. Climate Res. 37: 181-201. http://dx.doi.org/10.3354/cr00764.

SOTO, M., MARIGÓMEZ, I. \& CANCIO, I. 2003. Biological aspects of metal accumulation and storage. Zoology and Cell Biology Dept., Cell Biology and Histology Lab, Faculty of Science and Technology. University of the Basque Country.

STEGEMAN, J.J., BROUWER, M., RICHARD, T.D.G., FÖRLIN, L., FOWLER, B.A., SANDERS, B.M., VAN VELD, P.A. 1992. Molecular responses to environmental contamination: enzymes and protein systems as indicators of chemical exposure and effect. In: HUGGETT, R.J., KIMERLY, R.A., MEHRLE, P.M., JR BERGMAN, H.L. (Eds.), Biomarkers: Biochemical, Physiological and Histological markers of Anthropogenic Stress. Lewis Publishers, Chelsea, MI, USA, pp 235-335.

TOMASELLO, B., COPAT, C., PULVIRENTI, V., FERRITO, V., FERRANTE, V., FERRANTE, M., RENIS, M., SCIACCA, S. \&
TIGANO, C. 2012. Biochemical and bioaccumulation approaches for investigating marine pollution using Mediterranean rainbow wrasse, Coris julis (Linneaus 1798). Ecotoxicol. Environ. Safe. 86: 168-175. http://dx.doi.org/10.1016/j.ecoenv.2012.09.012.

TRIEBSKORN, R., KÖHLER, H-R., HONNEN, W., SCHRAMM, M., ADAMS, S.M. \& MÜLLER, E.F. 1997. Induction of heat shock proteins, changes in liver ultrastructure, and alterations of fish behavior: are these biomarkers related and are they useful to reflect the state of pollution in the field. J. Aquat. Ecosystem Stress Recovery 6: 57-73. http://dx.doi.org/10.1023/A:1008224301117.

VAN DER OOST, R., BEYER, J. \& VERMEULEN, N.P.E. 2003. Fish bioaccumulation and biomarkers in environmental risk assessment: a review. Environ. Toxicol. Pharmacol. 13: 149-157. http://dx.doi.org/10.1016/S1382-6689(02)00126-6.

VIARENGO, A., LOWE, D., BOLOGNESI, C., FABBRI, E. \& KOEHLER, A. 2007. The use of biomarkers in biomonitoring: a 2-tier approach assessing the level of pollutant induced stress syndrome in sentinel organisms. Comp. Biochem. Physiol. C 146: 281-300. http://dx.doi.org/10.1016/j.cbpc.2007.04.011.

VIEIRA, C.E.D., COSTA, P.G., LUNARDELLI, B., OLIVEIRA, L.F., CABRERA, L.C., RISSO, W.E., PRIMEL, E.G., MELETTI, P.C., FILLMANN, G. \& MARTINEZ, C.B.R. 2016. Multiple biomarker responses in Prochilodus lineatus subjected to short-term in situ exposure to streams from agricultural areas in Southern Brazil. Sci Total Environ. 542:44-56. http://dx.doi. org/10.1016/j.scitotenv.2015.10.071.

VIEIRA, L.R., GRAVATO, C., SOARES, A.M.V.M., MORGADO, F. \& GUILHERMINO, L. 2009. Acute effects of copper and Mercury on the estuarine fish Pomatoschistus microps: Linking biomarkers to behavior. Chemosphere 76: 1416-1427. http:// dx.doi.org/10.1016/j.chemosphere.2009.06.005.

WEBB, D. \& GAGNON, M.M. 2009. The value of stress protein 70 as an environmental biomarker of fish health under field conditions. Environ. Toxicol. 24: 287-295. http://dx.doi. org/10.1002/tox.20432.

WEBER, P., BEHR, E.R., KNORR, C.L., VENDRUSCOLO, D.S., FLORES, E.M.M., DRESSLER, V.L. \& BALDISSEROTTO, B. 2013. Metals in the water, sediment, and tissues of two fish species from different trophic levels in a subtropical Brazilian river. Microchem. J. 106: 61-66. http://dx.doi.org/10.1016/j. microc.2012.05.004.

WHEATLEY, R.A. 2000. Some recent trends in the analytical chemistry of lipid peroxidation. Trends in Analytical Chemistry 19, 617-628. http://dx.doi.org/10.1016/S0165-9936(00)00010-8.

WHYTE, J.J., JUNG, R.E., SCHMITT, C.J. \& TILLITT, D.E. 2000. Ethoxyresorufin-O-deethylase (EROD) activity in fish as a biomarker of chemical exposure. Crit. Rev. Toxicol. 30:347-570. http://dx.doi.org/10.1080/10408440091159239.

WUNDERLICH, A.C., SILVA, R.J., ZICA, E.O.P., REBELO, M.F., PARENTE, T.E.M. \& VIDAL-MARTÍNEZ, V.M. 2015. The influence of seasonality, fish size and reproductive status on EROD activity in Plagioscion squamosissimus: Implications for biomonitoring of tropical/subtropical reservoirs. Ecological Indicators 58:267-276. http://dx.doi.org/10.1016/j. ecolind.2015.05.063. 